\title{
Temporal variations of gas compositions of fumaroles in the Tatun Volcano Group, northern Taiwan
}

\author{
Hsiao-Fen Lee ${ }^{\text {a }}$, Tsanyao Frank Yang ${ }^{\text {a,* }}$, Tefang Faith Lan ${ }^{\text {a }}$, Cheng-Hong Chen ${ }^{\text {a }}$ \\ Sheng-Rong Song a , Shuhjong Tsao ${ }^{\mathrm{b}}$ \\ a Department of Geosciences, National Taiwan University, No. 1, Sec. 4, Roosevelt Road, Taipei 106, Taiwan \\ b Central Geological Survey, MOEA, P.O. Box 968, Taipei 235, Taiwan
}

\section{A R T I C L E I N F O}

\section{Article history:}

Received 15 October 2007

Accepted 10 June 2008

Available online 18 June 2008

\section{Keywords:}

Tatun Volcano Group

Taiwan

volcanic gases

${ }^{3} \mathrm{He} /{ }^{4} \mathrm{He}$

geochemical monitoring

\begin{abstract}
A B S T R A C T
Hydrothermal activity is common in the Tatun Volcano Group of northern Taiwan. Helium isotopic compositions of fumarolic samples show that mantle component occupies more than $60 \%$ in the previous study. Along with recent seismic results, a magma reservoir is inferred to have existed beneath the area of Da-you-keng, where fumarolic venting is the most active in Tatun Volcano Group. Progressive increases of $\mathrm{HCl}$ concentrations and $\mathrm{SO}_{2} / \mathrm{H}_{2} \mathrm{~S}$ ratio in fumaroles from Da-you-keng have been observed since August 2004. The $\mathrm{HCl}$ concentration changed from almost the detection limit to thousands of ppm, even up to 30,000 ppm. $\mathrm{SO}_{2} / \mathrm{H}_{2} \mathrm{~S}$ ratios varied from almost 0 to 3 ; hence $\mathrm{SO}_{2}$ became the dominated $\mathrm{S}$ species in this area. These variations were accompanied by rising temperature of fumaroles in the Tatun Volcano Group, especially in the area of Da-you-keng (from boiling point to $131{ }^{\circ} \mathrm{C}$ ). Meanwhile, ${ }^{3} \mathrm{He} /{ }^{4} \mathrm{He}$ ratios showed a decreasing trend but returned to normal values shortly thereafter. We propose two possible processes, 1 ) new magma supply and 2) recent opening of fractures in local area, to explain these observations. Based on the change of ${ }^{3} \mathrm{He} /{ }^{4} \mathrm{He}$ ratio and lack of ground deformation, we consider the latter might be more plausible.
\end{abstract}

(C) 2008 Elsevier B.V. All rights reserved.

\section{Introduction}

The variation of volcanic gas composition is considered as an important index of volcanic activity (e.g. Ohnishi and Kamada, 1981; Sano et al., 1984; Menyailov et al., 1986; Chiodini et al., 1993; Giggenbach, 1996; Notsu et al., 2001). Compositions of volcanic gases can help to understand the sources and origin of magmas in one area (e.g. Symonds et al., 1994; Giggenbach, 1996; Capasso et al, 1997; Giammanco et al, 1998; Yang et al., 2003b, 2005; Chen et al., 2005; Pecoraino and Giammanco, 2005). Previous studies have shown that the compositions of volcanic gas and some reactive gas ratios change dramatically before eruption (e.g. Noguchi and Kamiya, 1963; Walker, 1974; Oskarsson, 1984; Hirabayashi et al., 1986; Fischer et al., 1996; Duffell et al., 2003; Carapezza et al., 2004; Aiuppa and Federico, 2004; Capasso et al., 2005). Integrated with other available data/investigations, observations of chemical and isotopic compositions of volcanic gases can monitor the volcanic activity and predict forthcoming eruptions (e.g. Aramaki, 1991; Aiuppa et al., 2007).

Taiwan is located on the boundary of the Philippine Sea Plate and the East Asian continent that makes the tectonic setting not merely a collision zone but also a transform region between Luzon and Ryukyu

\footnotetext{
* Corresponding author. Tel.: +886 23366 5874; fax: +886223636095. E-mail address: tyyang@ntu.edu.tw (T.F. Yang).
}

subduction systems (Fig. 1A) (e.g. Teng et al., 1992; Teng, 1996; Wang et al., 1999). Situated at the northern tip of Taiwan, the Tatun Volcano Group (hereafter called the TVG) is a part of the Northern Taiwan Volcanic Zone. It also belongs to the southwest part of the Okinawa Trough which might be related to post-collisional collapse rather than arc volcanism (Wang et al., 1999). The TVG includes more than 20 Quaternary volcanoes which are mainly composed of andesitic lavas and pyroclastic flows (Chen and Wu, 1971). The most important geological structure in the TVG is the Chinshan Fault, which strikes in the NE-SW direction. The major fumaroles and hot springs are distributed along this reverse fault indicating that volcanic activities of the TVG may be associated with the activities of Chinshan Fault (Yen et al., 1984).

The eruption history of the TVG can be divided into two major periods according to the results of K-Ar dating (Juang and Chen, 1989; Tsao, 1994) and fission track analysis (Wang and Chen, 1990). The first eruptive period began around 2.5-2.8 Ma, then ceased after about one million years. The second period started $1.5 \mathrm{Ma}$ and continued until around 0.1-0.2 Ma (Song et al., 2000a). The TVG is considered dormant because of no previous historical eruptions, however, postvolcanic activities i.e., hot springs and gas fumaroles, are well developed now, suggesting that the TVG might not be extinct. Chen and Lin (2002) reported some volcanic ashes in sedimentary formations that are younger than about $20 \mathrm{ka}$ along with grains of charcoals in the Taipei Basin deposits. In addition, helium isotopic results from fumarolic gas demonstrate that more than $60 \%$ of helium 


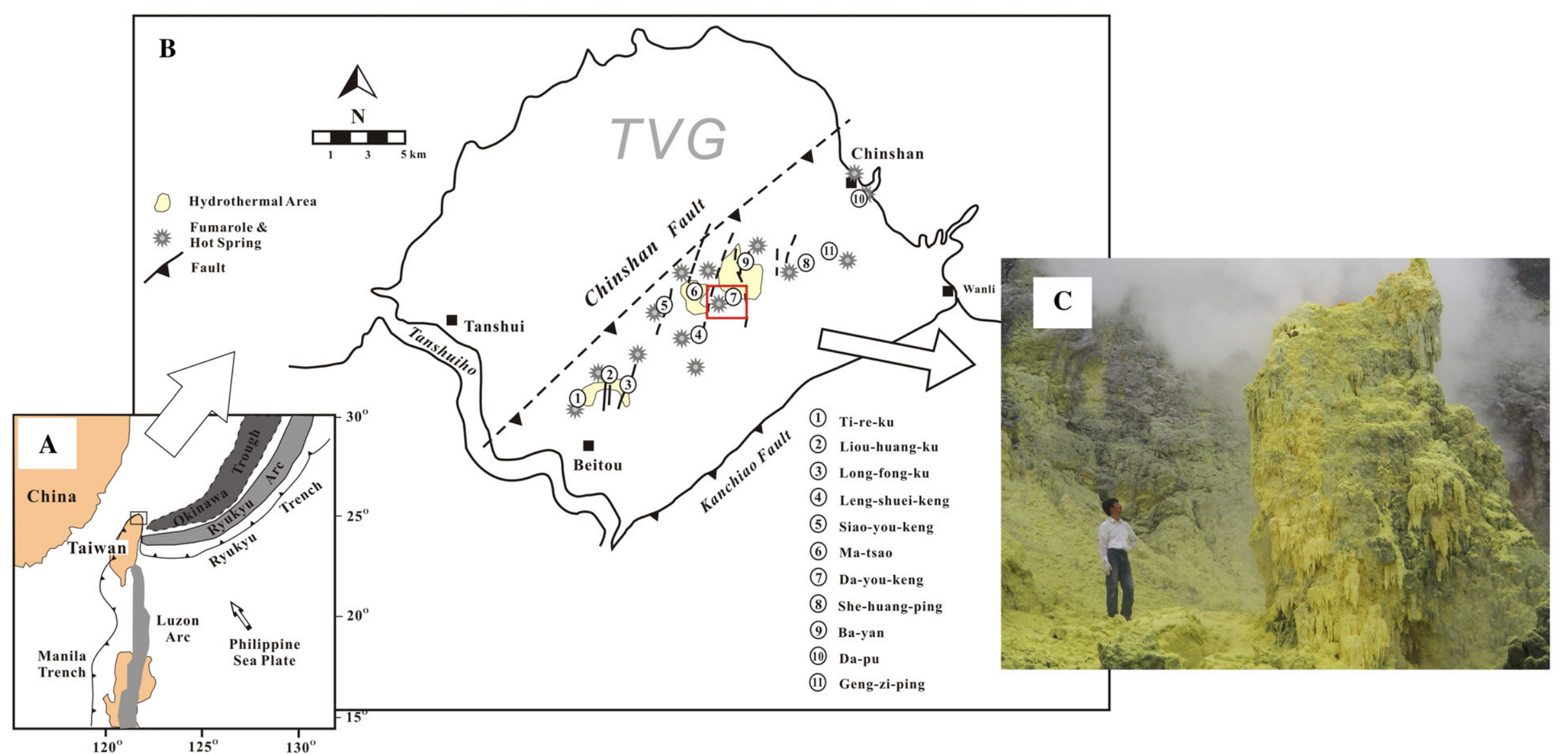

Fig. 1. (A) Sketch of the geologic setting of Taiwan. (B) Location of the Tatun Volcano Group (TVG) and sampling sites in this study. (C) Photograph of the biggest fumarole in Da-you-Keng (DYK). The cone has collapsed as of 2008. 
from the majority of sample sites exhibit mantle-derived characteristics (Yang et al., 1999; Yang, 2000), indicating that a magma chamber might still exist beneath the TVG area. It is therefore concluded that the TVG could still be active (Song et al., 2000b). Recent seismic observations recorded some volcano-seismic signals, which are considered to be most probably associated with the direct or indirect interaction between hydrothermal or magmatic fluids and solid rock in the upper crust (Lin et al., 2005a, b; Konstantinou et al., 2007). Helium isotopic data and seismic results point towards existence of a magma chamber underneath Northern Taiwan, particularly in the area of Da-you-keng (DYK) (Yang et al., 2003b; Lin et al., 2005a, b).

The TVG is about $15 \mathrm{~km}$ north of metropolitan Taipei which has more than seven million inhabitants. Also there are two nuclear power plants located only a few kilometers northeast of the TVG. Thus, monitoring potential volcanic activity in the Tatun area is an urgent task.

In this study we present the variations of volcanic gases in chemical and isotopic composition in the TVG from 2003 to 2006 and explain possible reasons for the observed phenomena. Since August 2004, fumarolic gas composition of DYK had not only a progressive increase in $\mathrm{HCl}$ concentration but also in $\mathrm{SO}_{2} / \mathrm{H}_{2} \mathrm{~S}$ ratio. Except for the fumaroles in the area of Leng-shuei-keng, the temperature of all measured fumaroles was higher than before, especially in DYK. Moreover, the total sulfur contents and $\mathrm{CO}_{2}$ flux of soil gas in Liu-Huang-Ku hydrothermal area in 2006 were higher than in 2004 (Lan et al., 2007). Besides, the ${ }^{3} \mathrm{He} /{ }^{4} \mathrm{He}$ ratio was quite steady in last few years but showed a decreasing trend in this period

Table 1

The average outlet temperature and dry gas compositions of fumaroles from the Tatun Volcano Group

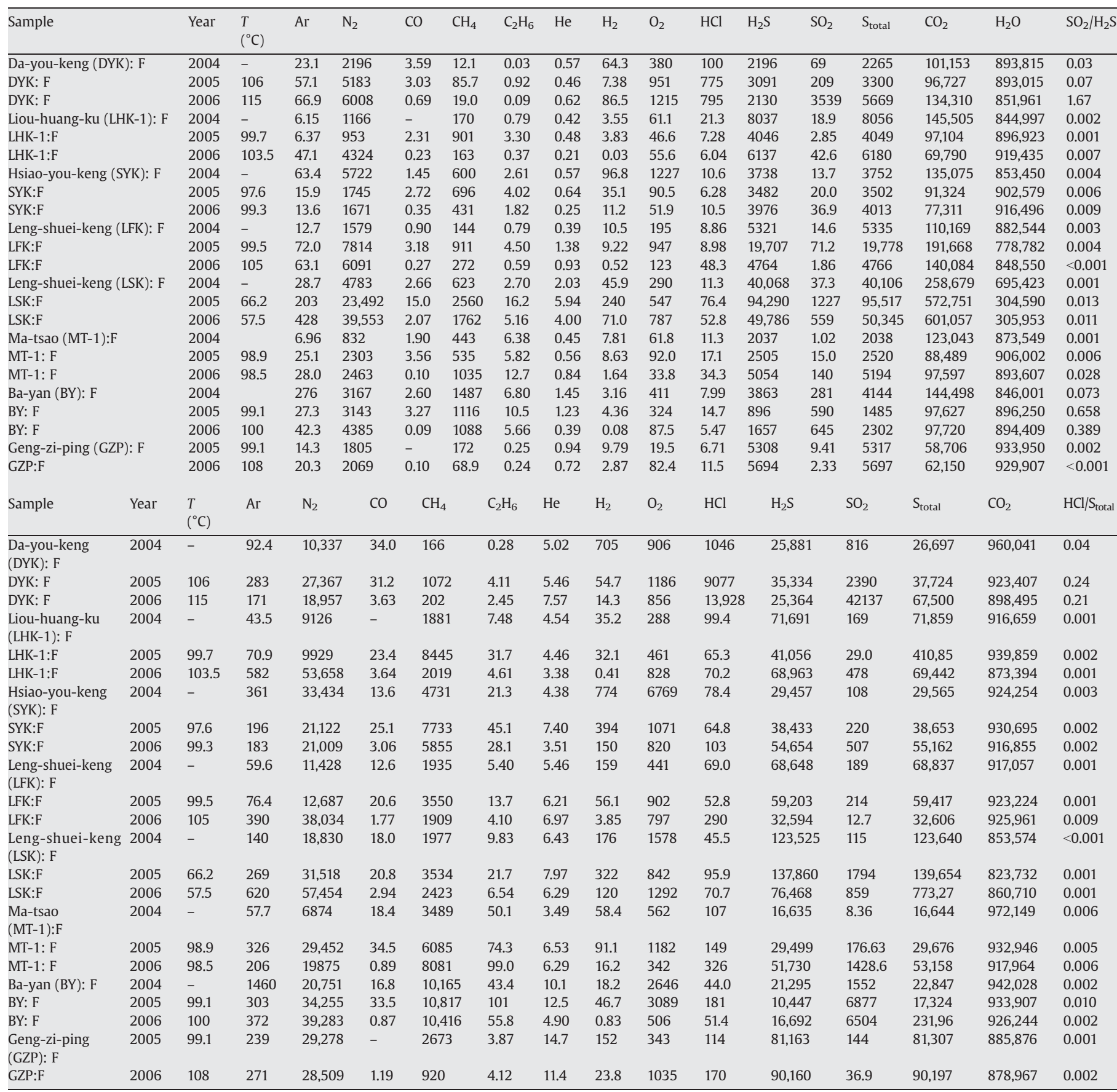

Note: Concentration is given in units of $\mu \mathrm{mol} / \mathrm{mol}$; F: fumaroles; $\mathrm{S}_{\text {total }}=\mathrm{SO}_{2}+\mathrm{H}_{2} \mathrm{~S}$; -: not analyzed or not detected. 
Table 2

The average temperature and dry compositions of the bubbling springs from the Tatun Volcano Group

\begin{tabular}{|c|c|c|c|c|c|c|c|c|c|c|c|c|c|c|c|c|}
\hline Sample & Year & $\begin{array}{l}T \\
\left({ }^{\circ} \mathrm{C}\right)\end{array}$ & $\mathrm{Ar}$ & $\mathrm{N}_{2}$ & $\mathrm{CO}$ & $\mathrm{CH}_{4}$ & $\mathrm{C}_{2} \mathrm{H}_{6}$ & $\mathrm{He}$ & $\mathrm{H}_{2}$ & $\mathrm{O}_{2}$ & $\mathrm{HCl}$ & $\mathrm{H}_{2} \mathrm{~S}$ & $\mathrm{SO}_{2}$ & $\mathrm{~S}_{\text {total }}$ & $\mathrm{CO}_{2}$ & $\mathrm{SO}_{2} / \mathrm{H}_{2} \mathrm{~S}$ \\
\hline Dapu (DP): B & $2004-$ & - & 354 & 53,674 & 17.0 & 28,190 & 44.5 & 35.5 & 14.8 & 4571 & 6346 & 1555 & 8.35 & 1563 & 905,197 & 0.005 \\
\hline DP: B & 2005 & 50.4 & 268 & 45,877 & 29.4 & 29,191 & 119 & 21.8 & 41.7 & 2059 & 974 & 728 & 4.46 & 732 & 920,698 & 0.006 \\
\hline DP: B & 2006 & 48.9 & 224 & 40,019 & 1.08 & 23,671 & 86.8 & 36.5 & 3.37 & 976 & 158 & 3084 & 100 & 3184 & 931,769 & 0.033 \\
\hline She-huang-ping (SHP): B & 2004 & - & 55.4 & 6258 & - & 1253 & 6.69 & 2.78 & 17.3 & 309 & 95.8 & 17,617 & 12.9 & 17,630 & 974,373 & 0.001 \\
\hline SHP: B F & 2005 & 99.4 & 100 & 11,583 & 20.9 & 4294 & 16.0 & 7.17 & 34.0 & 170 & 216 & 51,989 & 60.0 & 52,049 & 931,524 & 0.001 \\
\hline SHP: F & 2006 & 101 & 229 & 22,938 & 1.10 & 1794 & 4.21 & 5.48 & 3.34 & 772 & 68.6 & 48,001 & 923 & 48,925 & 925,521 & 0.019 \\
\hline Liou-huang-ku (LHK-2): B & 2004 & - & 253 & 24,593 & 9.86 & 3571 & 13.1 & 6.58 & 12.5 & 2857 & 82.4 & 31,355 & 151 & 31,506 & 937,096 & 0.005 \\
\hline LHK-2: B & 2005 & 50.8 & 187 & 19,550 & 24.7 & 11,181 & 37.3 & 6.24 & 23.0 & 1990 & 72.0 & 22,398 & 29.0 & 22,427 & 944,511 & 0.001 \\
\hline LHK-2: B & 2006 & 51.9 & 369 & 32,578 & 1.26 & 5943 & 13.3 & 8.59 & 2.61 & 1568 & 244 & 16,850 & 19.5 & 16,869 & 942,406 & 0.001 \\
\hline Ma-tsao (MT-2): B & 2004 & - & 144 & 17,046 & 14.7 & 12,577 & 125 & 9.79 & 62.8 & 1498 & 77.6 & 40,432 & 53.6 & 40,486 & 927,966 & 0.001 \\
\hline MT: B & 2005 & 64.5 & 143 & 12,727 & 25.2 & 9315 & 115 & 6.67 & 65.8 & 1457 & 73.9 & 18,331 & 80.7 & 18,412 & 957,670 & 0.004 \\
\hline MT: B & 2006 & 63.8 & 220 & 18,222 & 0.48 & 9385 & 117 & 7.86 & 22.7 & 588 & 99.5 & 16,090 & 86.5 & 16,176 & 955,252 & 0.005 \\
\hline Ti-re-ku (TRK): B & 2004 & - & 398 & 18,652 & 35.4 & 742 & 22.8 & 1.60 & 46.4 & 1975 & 10,696 & 8589 & 4.41 & 8593 & 95,8861 & 0.001 \\
\hline TRK: B & 2005 & 84.1 & 351 & 18,001 & 30.8 & 2524 & 48.2 & 6.39 & 34.6 & 1862 & 1190 & 8349 & 4.62 & 8353 & 967,618 & 0.001 \\
\hline TRK: B & 2006 & 87.2 & 618 & 38,319 & 2.98 & 1256 & 21.2 & - & 9.12 & 984 & 3629 & 10,431 & 90.5 & 10,522 & 944,841 & 0.009 \\
\hline
\end{tabular}

Note: Concentration is given in units of $\mu \mathrm{mol} / \mathrm{mol}$; B: hot spring bubbles; F: fumaroles; $\mathrm{S}_{\text {total }}=\mathrm{SO}_{2}+\mathrm{H}_{2} \mathrm{~S}$; -: not analyzed or not detected.

that lasted for approximately 6 months. These variations are probably correlated to local magma activity.

\section{Sampling and measurements}

Several fumaroles and hot springs are distributed from Beitou to Chinshan in the TVG area. Eleven sites were chosen for regular sampling (Fig. 1B). DYK is the most active and important geothermal area with one of biggest venting fumaroles (Fig. 1C) in the TVG because of its highest ${ }^{3} \mathrm{He} /{ }^{4} \mathrm{He}$ ratio $\left(\sim 6.8 R_{\mathrm{A}}\right.$. Yang et al., 2003b). ${ }^{3} \mathrm{He} /{ }^{4} \mathrm{He}$ ratios decrease southwestward and northeastward from DYK along the strike of Chinshan Fault (Yang et al., 1999, 2003b). Based on the helium isotopic data, Yang et al. (2003b) suggested that a magma chamber may exist underneath DYK. DYK is at an elevation of $1400 \mathrm{~m}$ and contains a host of fumaroles, sulfur vents, and hot springs. The fumaroles and vents continuously discharge stream and gases. There are two major fumaroles in DYK and the distance between them is about $100 \mathrm{~m}$. The bigger fumarole usually forms a high cone made of sulfur and ash, however, it collapses easily (Fig. 1C). For reasons of safety, the smaller fumarole which is located in a small platform is chosen as the regular sampling site. The gas compositions from DYK fumaroles, which are dominated by steam and $\mathrm{CO}_{2}$, are similar to other geothermal areas in the TVG. The minor components are sulfur species $\left(\mathrm{H}_{2} \mathrm{~S}\right.$ and $\left.\mathrm{SO}_{2}\right), \mathrm{N}_{2}$ and $\mathrm{CH}_{4}$. The $\mathrm{H}_{2} \mathrm{~S}$ concentrations are always much higher than $\mathrm{SO}_{2}$ in all fumarolic gases in the TVG (Lee et al., 2005).

Giggenbach (1975) described a reliable method for sampling volcanic gases, and the method is by far the most widely used. Following the method, samples were collected using Giggenbach-bottles which were evacuated and filled with $50 \mathrm{ml} 4 \mathrm{~N}$ alkali hydroxide solution. By using such method, dissolvable species like $\mathrm{H}_{2} \mathrm{O}, \mathrm{CO}_{2}, \mathrm{H}_{2} \mathrm{~S}, \mathrm{SO}_{2}$, and $\mathrm{HCl}$ are dissolved in the alkali hydroxide solution, whereas un-dissolvable species $\left(\mathrm{H}_{2}, \mathrm{~N}_{2}, \mathrm{Ar}, \mathrm{O}_{2}, \mathrm{He}, \mathrm{CO}, \mathrm{CH}_{4}\right)$ remain in the headspace gas phase of the bottle. To collect gas samples, a 1-m-long titanium tube was inserted into the fumaroles. To reduce air contamination, a hand pump was used to evacuate the air in the titanium tube first.

After sampling gases using the Giggenbach-bottle, we used a preevacuated low permeability potassium-glass bottle with two vacuum stopcocks at both ends to collect volcanic gases for helium isotopic analyses. To separate $\mathrm{H}_{2} \mathrm{~S}$ and $\mathrm{SO}_{2}$, iodine solution $(20 \mathrm{ml} 0.05 \mathrm{M})$ was prepared inside a bottle for fumarolic gas sampling in this study. $\mathrm{H}_{2} \mathrm{~S}$

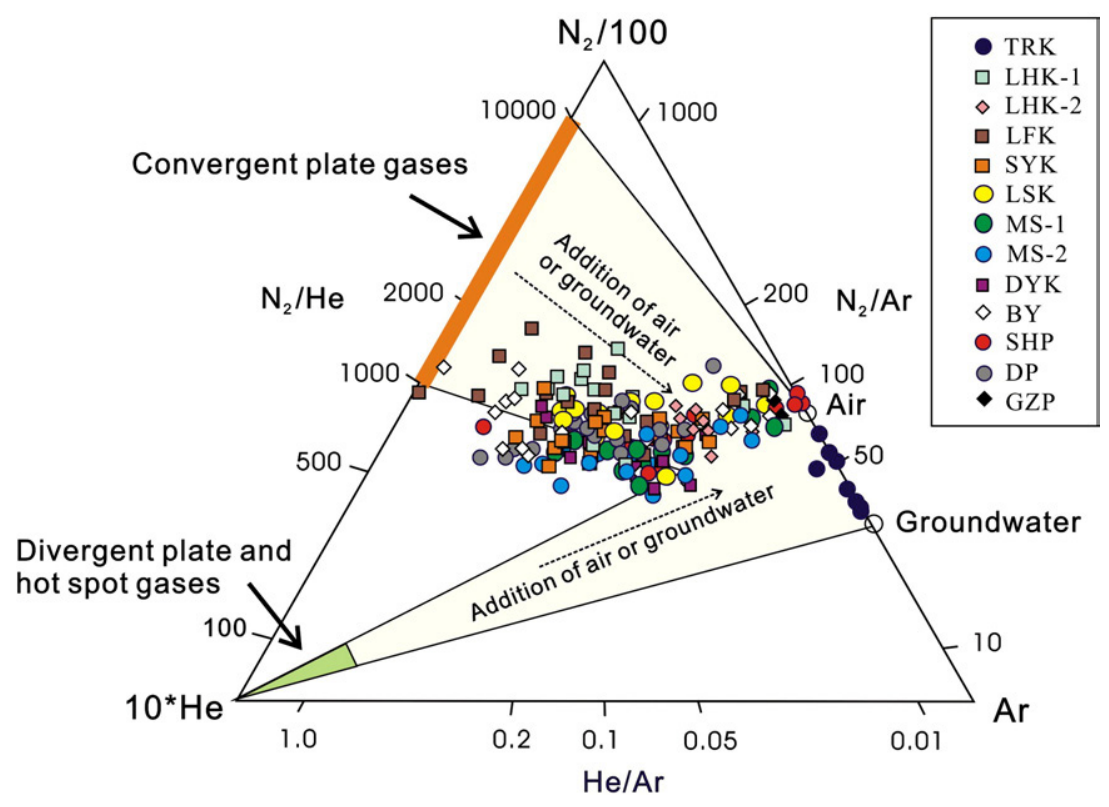

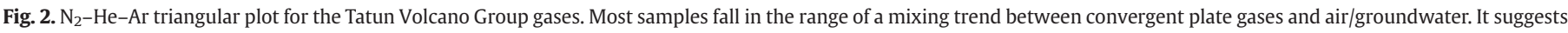

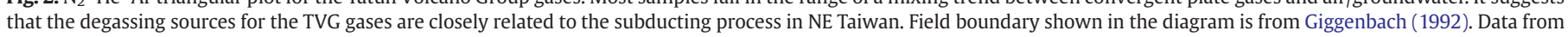
Lee et al. (2005) and this study. 
in the fumarolic gases reacts with the iodine solution and the reaction generates solid elemental sulfur as precipitate. $\mathrm{SO}_{2}$ reacts with iodine solution and turns into $\mathrm{SO}_{4}^{2-}$ which dissolves in the solution (Hirabayashi and Shinohara, 1989). The water replacement method was used to collect bubbles of hot springs.

The volcanic gas compositions of the headspace were analyzed by a gas chromatograph (GC, SRI 8610C) equipped with two thermal conductivity detectors (TCDs) and one flame ionic detector (FID) with methanizer. Hydrogen carrier gas is supplied to the FID and one TCD. Samples pass through a $1 \mathrm{~m}$ MS-13X (Molecular Sieve) column which is connected to a Rh-catalyst ( $\mathrm{Rh} 1.5 \%$ in $\mathrm{Al}_{2} \mathrm{O}_{3}$ ) oven and can detect the composition of $\mathrm{Ar}, \mathrm{N}_{2}$, and $\mathrm{CH}_{4}$ by TCD. Oxygen in the sample will become combustible by reaction with hydrogen carrier gas in the presence of the Rh-catalyst in the oven and at a temperature of $150{ }^{\circ} \mathrm{C}$. We switch the EPC (electronic pressure control) valve so that samples can pass through $4 \mathrm{~m}$ Hayesep-D column and methanizer $\left(380{ }^{\circ} \mathrm{C}\right)$, and then $\mathrm{CO}, \mathrm{CH}_{4}, \mathrm{CO}_{2}, \mathrm{C}_{2} \mathrm{H}_{6}$ can be detected by both TCD and FID. Another TCD with $4 \mathrm{~m}$ Molecular Sieve and argon as a carrier gas is used to analyze the concentrations of $\mathrm{He}, \mathrm{H}_{2} \mathrm{O}_{2}, \mathrm{~N}_{2}, \mathrm{CH}_{4}$, and $\mathrm{CO}_{2}$. Overall, the $\mathrm{GC}$ system can analyze compositions of $\mathrm{CH}_{4}, \mathrm{C}_{2} \mathrm{H}_{6}, \mathrm{CO}, \mathrm{CO}_{2}$, $\mathrm{Ar}, \mathrm{N}_{2}, \mathrm{H}_{2}$, He and $\mathrm{O}_{2}$, simultaneously in one single sample loading. The un-dissolvable gases in the headspace of Giggenbach-bottle had to be analyzed first in order to avoid air contamination which could easily happen while removing the alkali solution from the bottle. Afterward, the solution was extracted and analyzed with an ion chromatograph (IC, Metrohm 790 Personal) to determine the concentration of $\mathrm{HCl}$ and total sulfur in the sample. For measuring $\mathrm{CO}_{2}$ concentration in gas sample, the titration method was applied (Metrohm 702 SM Titrion) by assuming that all of the $\mathrm{CO}_{2}$ inside the sample had been dissolved as $\mathrm{CO}_{3}^{2-}$ in the alkali solution (Giggenbach, 1975). When the volcanic gases pass through iodine solution, $\mathrm{H}_{2} \mathrm{~S}$ will become precipitated sulfur and $\mathrm{SO}_{2}$ will dissolve in the solution. Thus, we can separate $\mathrm{SO}_{2}$ from precipitates using a filter paper. The filtrate can be used for IC analysis to determine the $\mathrm{SO}_{2}$ concentration. Consequently, the precipitate part is heated in a vial, which is filled with alkali solution. After the precipitated sulfur is dissolved, $\mathrm{H}_{2} \mathrm{O}_{2}$ is added to convert $\mathrm{SO}_{3}^{2-}$ into $\mathrm{SO}_{4}^{2-}$. Then, the solution can be analyzed to determine the concentration of $\mathrm{H}_{2} \mathrm{~S}$. Detailed setups and discussions of accuracy/precision and detection limits of all gas compositions follow Lee (2004) and Lee et al. (2005).

Gas samples collected in the potassium-glass bottles were used for analyses of the concentrations and isotopic ratios of helium, neon and other noble gases. ${ }^{3} \mathrm{He} /{ }^{4} \mathrm{He}$ and ${ }^{4} \mathrm{He} /{ }^{20} \mathrm{Ne}$ ratios were analyzed by a high-precision noble gas mass spectrometer (Micromass 5400) with dual collectors in the Department of Geosciences, National Taiwan University. Observed ${ }^{3} \mathrm{He} /{ }^{4} \mathrm{He}$ ratios were calibrated against atmospheric standard gas and normalized to $R_{\mathrm{A}}$ (the ${ }^{3} \mathrm{He} /{ }^{4} \mathrm{He}$ ratio in air, $1.39 \times 10^{-6}$ ). Details of the measurements of helium isotopic ratios had been described by Yang (2000) and Yang et al. (2005, 2006).

\section{Results and discussions}

\subsection{Spatial variations of gas compositions}

The gas compositions of the TVG were found to be similar to those from all other low-temperature fumaroles in the world (Goff and McMurtry, 2000). The dominant species is $\mathrm{H}_{2} \mathrm{O}$, followed by $\mathrm{CO}_{2}, \mathrm{H}_{2} \mathrm{~S}$, $\mathrm{N}_{2}$ and $\mathrm{CH}_{4}$ (Tables 1 and 2). The outlet temperatures for these

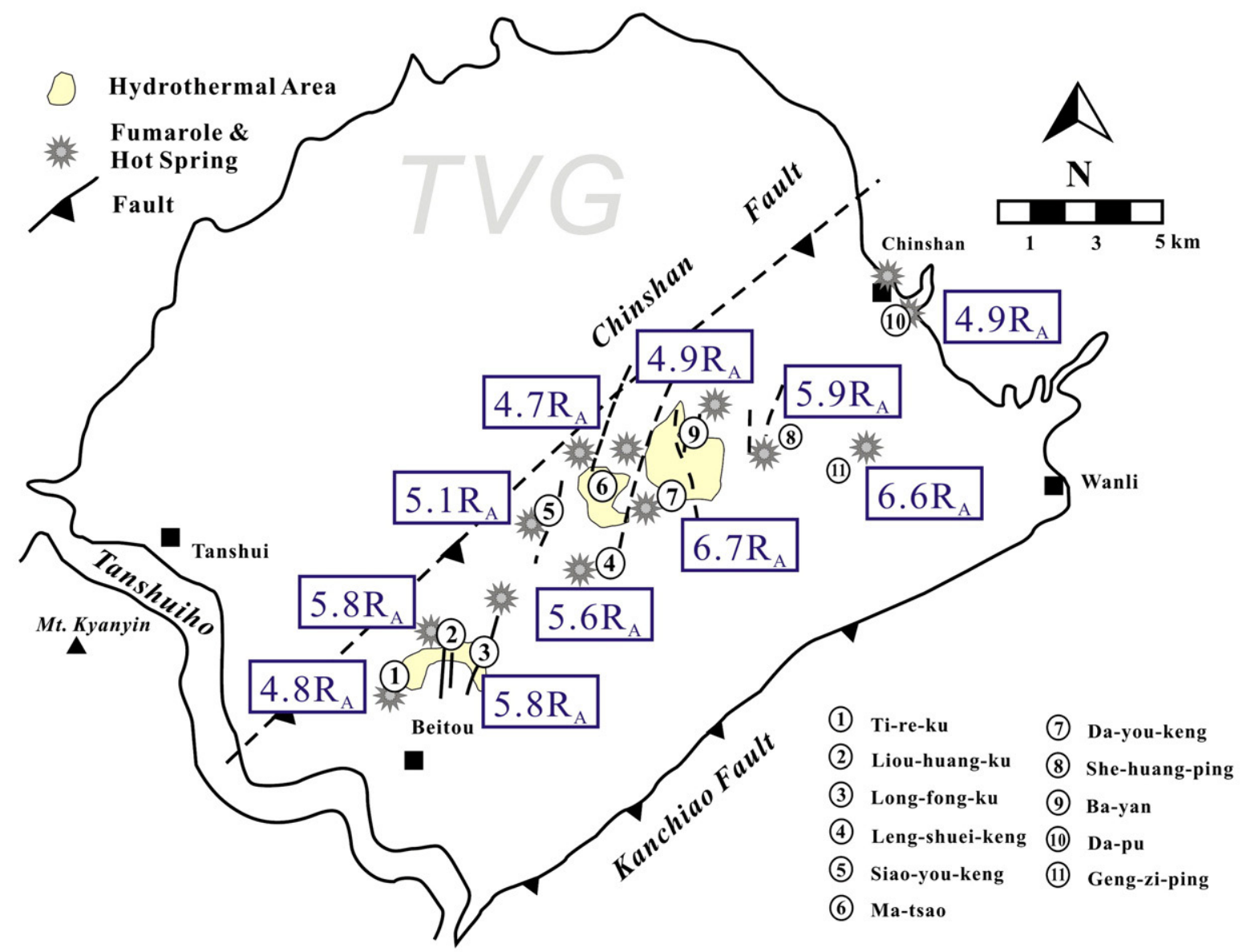

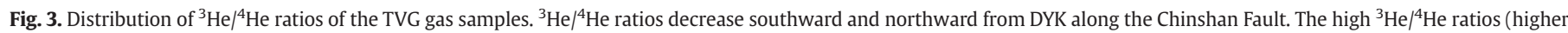
than ${ }^{3} \mathrm{He} /{ }^{4} \mathrm{He}$ ratio in air) suggested that He is predominantly of upper mantle origin in the TVG area. The figure is modified from Yang et al. (2003b). 
fumaroles were around boiling point $\left(57.5-115{ }^{\circ} \mathrm{C}\right.$, the average temperature). Different tectonic environments of the gases were differentiated by plotting the gas compositions on the $\mathrm{N}_{2}-\mathrm{He}-\mathrm{Ar}$ diagram (Giggenbach, 1992). In this diagram the gas composition is described in terms of the three end members, meteoric (air and airsaturated water), mantle-derived, and arc type fluids. Based on the relative amounts of $\mathrm{N}_{2}, \mathrm{Ar}$, and $\mathrm{He}$, most samples of the TVG gases exhibited the affinity of convergent plate gases (Fig. 2). It suggests that the degassing sources for the TVG gases were closely related to the subducting process in NE Taiwan.

Helium isotope ratio $\left({ }^{3} \mathrm{He} /{ }^{4} \mathrm{He}\right)$ of fumaroles and hot springs provides information on the activity and source of magma (Sano and Wakita, 1985; Marty et a1., 1989; Yang et al., 2003a). A postulated magma chamber may exist underneath DYK and the ${ }^{3} \mathrm{He} /{ }^{4} \mathrm{He}$ ratios decrease southwestward and northeastward from DYK along the Chinshan Fault (Fig. 3) (Yang et al., 2003b). However, there was a gap in this systematical trend. Ma-tsao (MT) hydrothermal area is very close to DYK hydrothermal area which has the highest ${ }^{3} \mathrm{He} /{ }^{4} \mathrm{He}$ ratio in the TVG. Nevertheless, the lowest ${ }^{3} \mathrm{He} /{ }^{4} \mathrm{He}$ ratio in the TVG was observed in MT ( $\left.4.7 R_{\mathrm{A}}\right)$. Distribution of ${ }^{3} \mathrm{He} /{ }^{4} \mathrm{He}$ ratios did not fit the linear change described above. This result might be caused by geological structures. Still, ${ }^{3} \mathrm{He} /{ }^{4} \mathrm{He}$ ratios of samples from the TVG were much higher than ${ }^{3} \mathrm{He} /{ }^{4} \mathrm{He}$ ratio in air. It suggested that $\mathrm{He}$ is predominantly of upper mantle origin in the TVG area.

In general, the gas compositions of fumarolic samples from the studied area all exhibited much lower concentration of $\mathrm{HCl}$ than other volcanoes in the world (Goff and McMurtry, 2000; Fischer, 2008). $\mathrm{SO}_{2} /$ $\mathrm{H}_{2} \mathrm{~S}$ ratio is also an important proxy to determine the gas sources. The $\mathrm{SO}_{2} / \mathrm{H}_{2} \mathrm{~S}$ ratios of the TVG area were found to be similar to those from other low-temperature volcanic gases in the world, i.e. $\mathrm{SO}_{2} / \mathrm{H}_{2} \mathrm{~S}$ ratio $<1$ (Lee et al., 2005). For the purpose of using geothermal energy, a lot of geothermal explorations have been done in the TVG area (MRSO, 1969, 1970, 1971, 1973). Two geothermal wells, E208 and E204 which are 1250-1500 m and $1400 \mathrm{~m}$ deep, respectively, were drilled in Ma-tsao area. The geothermal wells tapped acid sulfate-chloride water caused by the dissolution of acidic volcanic gases, especially $\mathrm{HCl}$ and $\mathrm{SO}_{2}$ in the water phase (Chen, 1970). The acidic-sulfate-chloride water could be associated with the variations of $\mathrm{HCl}$ concentration and $\mathrm{SO}_{2} / \mathrm{H}_{2} \mathrm{~S}$ ratio.

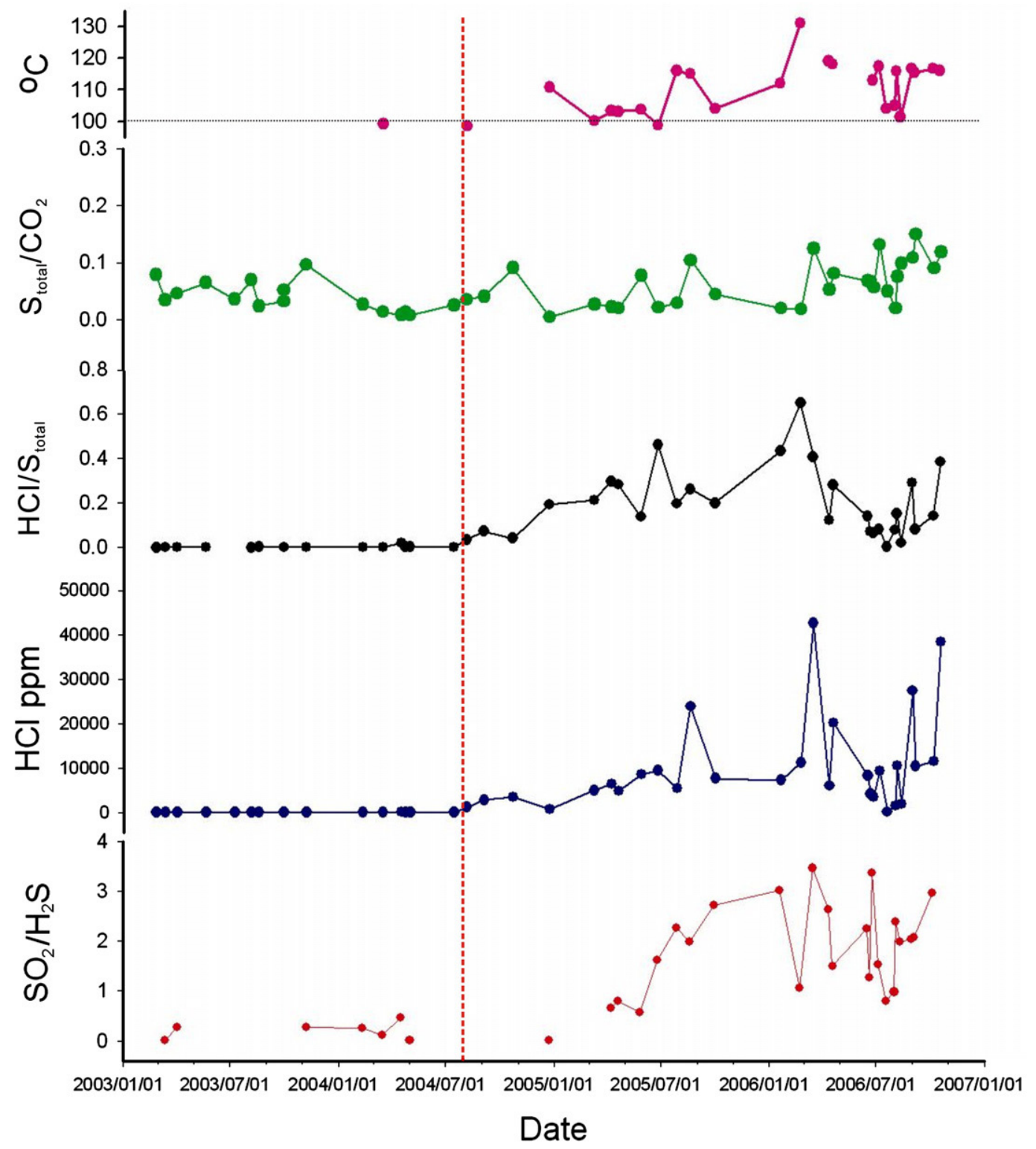

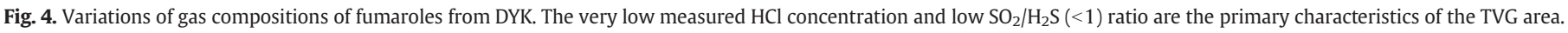

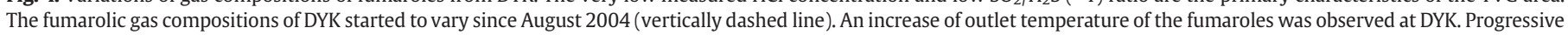
increases of $\mathrm{HCl}$ concentrations and $\mathrm{SO}_{2} / \mathrm{H}_{2} \mathrm{~S}$ ratios in DYK fumarolic gases were also observed. 
The springs in the TVG area are classified into volcanic and sedimentary types depend on their different aquifers. Spring waters of the volcanic type are mainly supplied by volcanic gases and andesitic rocks, while those of the sedimentary type are from volcanic gases, rhyolitic pebbles and brines in the Wuchihshan Formation (sandstone). Some hot springs located near the sea might be also affected by seawater (Liu et al., 1984; Chen et al., 2001). According to sulfur and hydrogen isotope, petrography and resistivity data, Liu et al. (1984) inferred that another shallow aquifer in depth of 300-600 m should exist at the volcanic rock formation. This aquifer might be divided into several individual segments because of the faults and fractures. The high concentration of $\mathrm{CH}_{4}$ in gas compositions (Table 1) and temperatures which approach to boiling point both indicate that vapor separated from boiling water near the surface, probably separated from this aquifer(s).

\subsection{Temporal variations of gas compositions}

From 1999 to $2003,{ }^{3} \mathrm{He} /{ }^{4} \mathrm{He}$ ratios and other gas components did not show significant variations, implying that the degassing system in the studied area was quite stable (Yang et al., 2003b). From 2003 on particularly since August 2004, fumarolic gases sampled from DYK present significant increases not only in $\mathrm{HCl}$ concentration but also in $\mathrm{SO}_{2} / \mathrm{H}_{2} \mathrm{~S}$ ratio. The increase of $\mathrm{SO}_{2} / \mathrm{H}_{2} \mathrm{~S}$ ratio is consistent with the result of recent in situ real time measurement at DYK (Witt et al., 2008-this issue). The outlet temperature of fumaroles in the TVG was
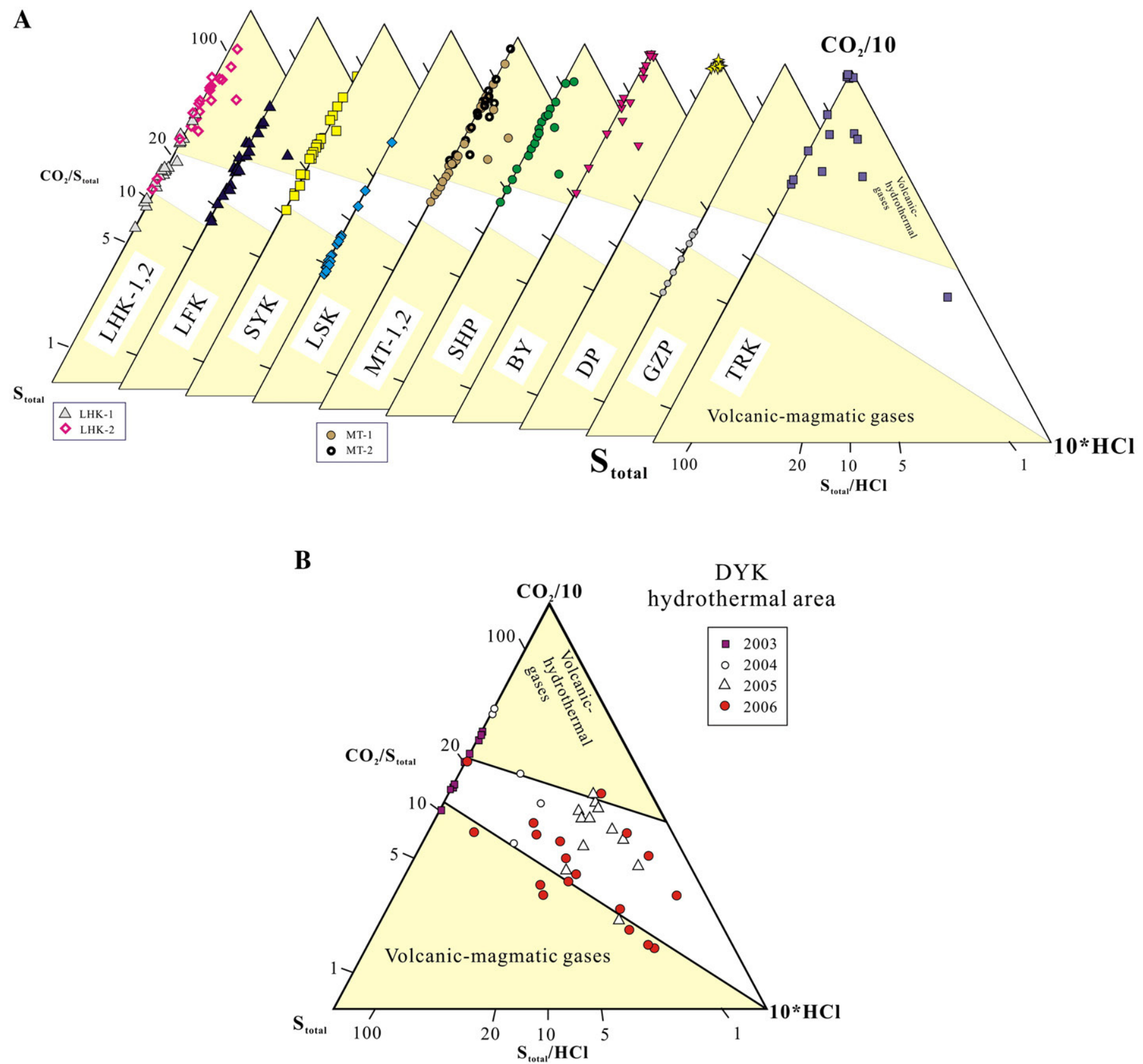

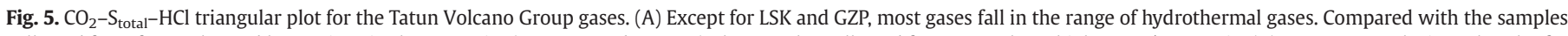

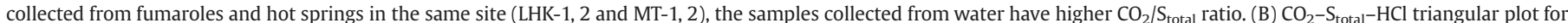

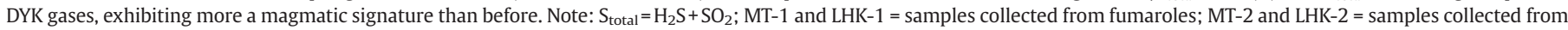

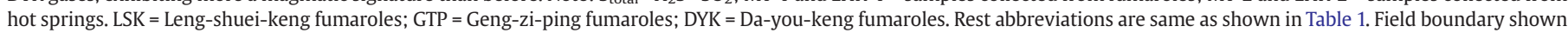
in the figure is from Giggenbach (1992). Data from Lee at al. (2005) and this study. 
also higher than before, especially in DYK (Fig. 4). The highest outlet temperature of fumaroles in DYK was recorded to be $131{ }^{\circ} \mathrm{C}$ in February 2006, and the temperature has been almost constant at $116^{\circ} \mathrm{C}$ since then (Fig. 4). The outlet temperature of fumaroles located in other hydrothermal areas also increased slightly, in the range of 5 to $10{ }^{\circ} \mathrm{C}$. For instance, the temperature of fumaroles located in LHK hydrothermal area changed from 97.6 to $106{ }^{\circ} \mathrm{C}$. Besides, Lan et al. (2007) reported that soil temperature in LHK hydrothermal area was also higher in 2006 than in 2004.

$\mathrm{HCl}$ concentration is easily affected by water because of its high solubility. $\mathrm{HCl}$ may be lost or gained for the ascending gas due to a hydrothermal system. Although $\mathrm{HCl}$ concentration was variable, there was a quite obvious increase of $\mathrm{HCl}$ concentration in DYK (Fig. 4). The main $\mathrm{Cl}$ species in magmas are alkali chlorides, and $\mathrm{HCl}$ is released during shallow degassing. For low-temperature discharging (i.e. temperature $<200{ }^{\circ} \mathrm{C}$ ), $\mathrm{HCl}$ concentrations are generally low, except for some discharges affected by rapid heating (Giggenbach, 1996). Almost all boiling-point fumaroles in the world have low $\mathrm{HCl}$ because most they are derived from a boiling aquifer beneath a fumarolic field.

As we know that seawater contributes a little part to the spring water of Chinshan and Dapu near the sea, it may be considered that the increase of $\mathrm{HCl}$ concentration in DYK area was caused by sea-water intrusion. The probable intruded pathway of seawater could go along the Chinshan Fault. If $\mathrm{HCl}$ concentration increased by sea-water intrusion indeed, all hydrothermal areas near the fault/sea should be affected. Nevertheless, this anomaly of $\mathrm{HCl}$ was only observed in DYK area where is located in the middle part of the Chinshan Fault. On the other hand, sea-water intrusion cannot cause temperature rise. The outlet temperature of fumaroles in DYK had risen for $10-20^{\circ}$ degrees in the past two years. The sea-water intrusion is not suitable to account for the $\mathrm{HCl}$ concentration increase.

$\mathrm{HCl}$ and $\mathrm{SO}_{2}$ are easily dissolved in water. $\mathrm{H}_{2} \mathrm{~S}$ and $\mathrm{SO}_{2}$ are the dominant $\mathrm{S}$ species in volcanic gases and usually magmatic in origin. The solubility and relative proportions of the $\mathrm{SO}_{2}$ and $\mathrm{H}_{2} \mathrm{~S}$ are strong functions of the composition and redox state of the melt (Haughton et al., 1974; Wallace and Carmichael, 1992). At a given $\mathrm{O}_{2}$ fugacity, sulfur occurs as $\mathrm{SO}_{2}$ at high temperature and as $\mathrm{H}_{2} \mathrm{~S}$ at lower temperature. Giggenbach (1987) suggested that Eq. (1) is important for a degassing magma during its ascend towards the surface.

$\mathrm{SO}_{2}+3 \mathrm{H}_{2} \leftrightarrow \mathrm{H}_{2} \mathrm{~S}+2 \mathrm{H}_{2} \mathrm{O}$

Thermodynamic modeling indicates that the reaction shifts to the right at high pressures (i.e. the magma degasses at great depths), thus $\mathrm{H}_{2} \mathrm{~S}$ is the dominant sulfur species in the gas. Conversely, hot gases escaping from a magma body emplaced at shallow levels in the crust will tend to be $\mathrm{SO}_{2}$-dominated, as frequently observed in the field (Giggenbach, 1987). Therefore, the $\mathrm{SO}_{2} / \mathrm{H}_{2} \mathrm{~S}$ ratio can be an important indicator of magma activity.

The appearance of $\mathrm{HCl}$ and $\mathrm{SO}_{2}$ in fumarolic gases in DYK could be related to the boiling of acidic sulfate-chloride water from the geothermal wells in the MT area, close to DYK. This deep aquifer (1250-1500 $\mathrm{m}$ deep) is assumed as the primary hydrothermal system (PHS) for the main source of the acid sulfate-chloride hot springs. The low concentration of $\mathrm{HCl}$ and $\mathrm{SO}_{2}$ in gas compositions of fumaroles indicates that fumarolic gases cannot be generated from this acid sulfate-chloride water directly. The fumarolic gases could be produced by mixing meteoric water, the shallow aquifer (secondary hydrothermal system, SHS), with vapor phases generated by evaporation of primary hydrothermal system. More volcanic gases were released in association with magma activity and caused the increase of $\mathrm{HCl}$ and $\mathrm{SO}_{2} / \mathrm{H}_{2} \mathrm{~S}$ ratio in DYK.

Since $\mathrm{CO}_{2}$ and sulfur species (including $\mathrm{H}_{2} \mathrm{~S}$ and $\mathrm{SO}_{2}$ ) are the major components in fumarolic gases, $\mathrm{CO}_{2} / \mathrm{S}_{\text {total }}$ ratio has been suggested as useful proxy to identify their sources (Giggenbach, 1992, 1996). More significant contributions of magmatic gases or limited influence of aquifers can produce higher concentration of sulfur species. Gases originated from magmatic source usually have higher total sulfur concentrations and hence, exhibit lower $\mathrm{CO}_{2} / \mathrm{S}_{\text {total }}$ ratios $(<10)$. In contrast, hydrothermal gases exhibit lower total sulfur concentrations and higher $\mathrm{CO}_{2} / \mathrm{S}_{\text {total }}$ ratios. By plotting $\mathrm{CO}_{2}-\mathrm{S}_{\text {total }}-\mathrm{HCl}$ as a ternary diagram, the $\mathrm{CO}_{2}$ corner can be considered as a low-temperature extreme, and sulfur species can be taken as the main indicator of a magmatic influence. Most of the TVG gases belong to the hydrothermal gases because of their high $\mathrm{CO}_{2} / \mathrm{S}_{\text {total }}$ ratios (Fig. $5 \mathrm{~A}$ ) (Lee et al., 2005). Based on this ternary diagram, we can recognize that DYK gases exhibited a more magmatic signature than before (Fig. 5B).

As described above, more than $60 \%$ of the helium is mantle-derived for fumaroles in most of the sampling sites in the TVG, and the highest ${ }^{3} \mathrm{He} /{ }^{4} \mathrm{He}$ ratio was obtained from the fumarolic gas of DYK (Yang et al., 1999). The ${ }^{3} \mathrm{He} /{ }^{4} \mathrm{He}$ ratio had been kept at a constant level in DYK from 1999 to 2004. However, it changed during a few months after August 2004 with a decreasing trend, and returned to prior values after approximately 6 months (Table 3, Fig. 6).

The ${ }^{3} \mathrm{He} /{ }^{4} \mathrm{He}$ ratio may increase if new magmatic material is added to the source, or it is decreased when more crustal material is added during the ascent of the gases. The decrease of the ${ }^{3} \mathrm{He} /{ }^{4} \mathrm{He}$ ratio in

Table 3

The ${ }^{4} \mathrm{He} /{ }^{20} \mathrm{Ne}$ and ${ }^{3} \mathrm{He} /{ }^{4} \mathrm{He}$ data of DYK fumaroles from 2003 to 2006

\begin{tabular}{|c|c|c|c|c|c|c|}
\hline Sample no. ${ }^{a}$ & ${ }^{4} \mathrm{He} /{ }^{20} \mathrm{Ne}$ & ${ }^{3} \mathrm{He} /{ }^{4} \mathrm{He}\left(\times 10^{-6}\right)$ & {$\left[R / R_{\mathrm{A}}\right]^{\mathrm{b}}$} & {$\left[R / R_{\mathrm{A}}\right]_{\mathrm{c}}{ }^{\mathrm{c}}$} & $\pm 1 \sigma$ & Note \\
\hline 20030226-DYK-1 & 3.59 & 8.12 & 5.84 & 6.32 & 0.40 & \\
\hline 20030313-DYK-1 & 25.1 & 9.34 & 6.72 & 6.79 & 0.10 & \\
\hline 20030402-DYK-1 & 75.0 & 9.44 & 6.79 & 6.81 & 0.10 & \\
\hline 20030521-DYK-1 & 133 & 9.18 & 6.60 & 6.62 & 0.11 & \\
\hline \multirow[t]{2}{*}{ 20030709-DYK-1 } & 37.9 & 10.58 & 7.61 & 7.67 & 0.12 & \\
\hline & 38.4 & 10.54 & 7.58 & 7.64 & 0.14 & Duplicate \\
\hline 20030723-DYK-2 & 4.34 & 8.61 & 6.19 & 6.60 & 0.10 & \\
\hline 20030930-DYK-1 & 2.12 & 7.95 & 5.72 & 6.56 & 0.10 & \\
\hline 20031107-DYK-2 & 4.70 & 8.38 & 6.03 & 6.40 & 0.09 & \\
\hline 20040211-DYK-1 & 6.47 & 9.62 & 6.92 & 7.23 & 0.10 & \\
\hline 20040501-DYK-1 & 37.0 & 9.47 & 6.82 & 6.87 & 0.09 & \\
\hline 20040527-DYK-1 & 6.67 & 8.59 & 6.18 & 6.44 & 0.16 & \\
\hline 20040714-DYK-1 & 1.13 & 7.59 & 5.46 & 7.22 & 0.11 & \\
\hline \multirow[t]{2}{*}{ 20041022-DYK } & 47.9 & 9.34 & 6.72 & 6.76 & 0.11 & \\
\hline & & 9.41 & 6.77 & 6.79 & 0.11 & Duplicate \\
\hline 20041107-DYK (G) & 1.32 & 7.56 & 5.44 & 6.85 & 0.10 & \\
\hline 20041215-DYK-1 & 18.9 & 7.55 & 5.43 & 5.51 & 0.08 & \\
\hline 20041223-DYK & 7.92 & 9.16 & 6.59 & 6.83 & 0.10 & \\
\hline 20050307-DYK-1 & 7.36 & 8.57 & 6.17 & 6.40 & 0.09 & \\
\hline 20050407-DYK & 14.7 & 8.93 & 6.43 & 6.55 & 0.09 & \\
\hline 20050419-DYK-1 & 8.25 & 7.99 & 5.75 & 5.94 & 0.09 & \\
\hline 20050527-DYK-1 & 9.16 & 9.25 & 6.65 & 6.86 & 0.11 & \\
\hline 20050625-DYK & 8.06 & 8.14 & 5.86 & 6.06 & 0.09 & \\
\hline 20050727-DYK & 5.33 & 6.68 & 4.81 & 5.05 & 0.07 & \\
\hline 20050930-DYK & 3.34 & 6.48 & 4.66 & 5.05 & 0.11 & \\
\hline 20051119-DYK & 71.1 & 8.18 & 5.89 & 5.91 & 0.09 & \\
\hline 20060214-DYK & 8.03 & 9.26 & 6.66 & 6.89 & 0.12 & \\
\hline 20060222-DYK-2 & 10.3 & 9.41 & 6.77 & 6.96 & 0.11 & \\
\hline 20060315-DYK & 36.6 & 9.72 & 6.99 & 7.04 & 0.11 & \\
\hline 20060411-DYK & 43.7 & 9.17 & 6.60 & 6.64 & 0.14 & \\
\hline 20060418-DYK & 35.9 & 9.01 & 6.48 & 6.53 & 0.15 & \\
\hline 20060422-DYK & 59.8 & 9.76 & 7.02 & 7.05 & 0.10 & \\
\hline 20060509-DYK & 61.9 & 9.54 & 6.87 & 6.90 & 0.10 & \\
\hline 20060525-DYK & 42.7 & 9.75 & 7.01 & 7.06 & 0.10 & \\
\hline 20060615-DYK & 53.3 & 9.59 & 6.90 & 6.93 & 0.10 & \\
\hline 20060620-DYK & 2.54 & 8.29 & 5.96 & 6.68 & 0.26 & \\
\hline 20060705-DYK & 9.20 & 9.47 & 6.82 & 7.02 & 0.10 & \\
\hline 20060718-DYK & 9.20 & 9.17 & 6.60 & 6.80 & 0.11 & \\
\hline 20060801-DYK & 39.4 & 9.54 & 6.86 & 6.91 & 0.10 & \\
\hline 20060811-DYK & 17.0 & 9.40 & 6.76 & 6.87 & 0.10 & \\
\hline 20060904-DYK & 6.62 & 9.33 & 6.72 & 7.00 & 0.10 & \\
\hline 20061005-DYK & 5.19 & 8.12 & 5.84 & 6.16 & 0.09 & \\
\hline Air & 0.319 & 1.39 & 1.00 & & & \\
\hline
\end{tabular}

a The affix of the sample name (20041022-) is the sampling date (2004/10/22).

b $R:{ }^{3} \mathrm{He} /{ }^{4} \mathrm{He}$ ratio of measured samples; $R_{\mathrm{A}}$ : ratio of air $\left(=1.39 \times 10^{-6}\right)$.

$\left[R / R_{\mathrm{A}}\right]_{\mathrm{c}}$ : air corrected helium isotopic ratio, assuming all the Ne derived from the air (Poreda and Craig, 1989). 


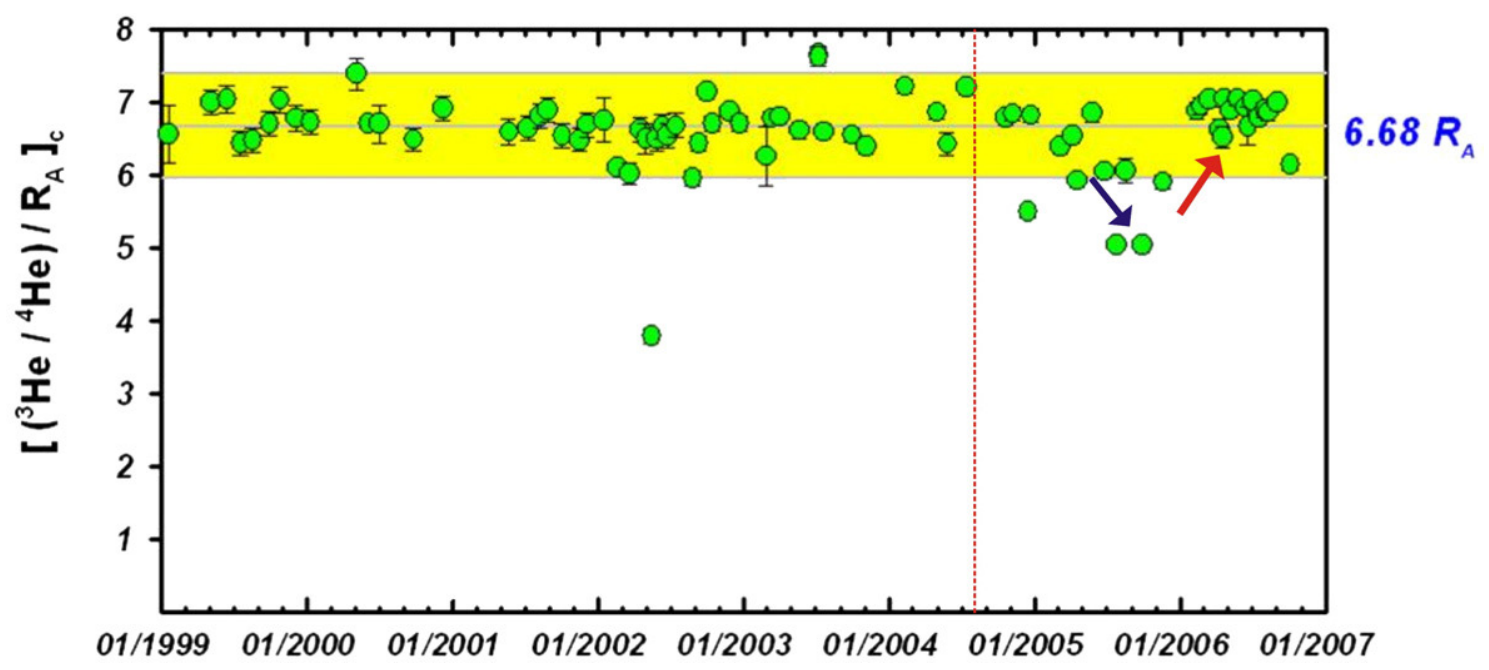

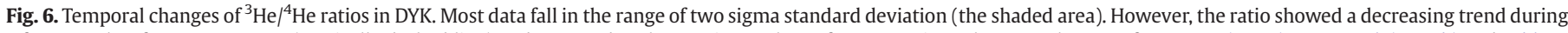

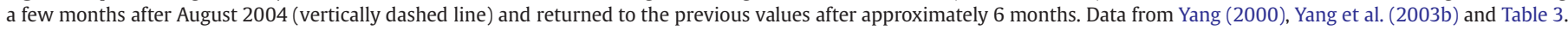

DYK was considered to be affected by crustal contamination when gases ascended to the surface. Consequently, the value returned to normal after the event stopped. However, the decreasing trend could also be caused by kinetic fractionation, which is generally significant in light molecules, during magma ascent as was recently suggested by Rizzo et al. (2006) for variations observed at Mt. Etna. In isotope mass fractionation, the light mass $\left({ }^{3} \mathrm{He}\right)$ diffuses very fast into the gas phase and is depleted in the residual melt. This process can be modeled by Rayleigh's distillation:

$F^{(k-1)}=\frac{R}{R_{0}}$

where $R$ is the ${ }^{3} \mathrm{He} /{ }^{4} \mathrm{He}$ ratio in melt, $F$ is the residual fraction of helium after a degassing event, the subscript "0" refers to initial conditions $\left({ }^{3} \mathrm{He} /{ }^{4} \mathrm{He}\right.$ in melt before the degassing event) and $k$ is the kinetic fractionation factor. Eq. (2) predicts that degassing causes a decrease of the ${ }^{3} \mathrm{He} /{ }^{4} \mathrm{He}$ ratio in the melt, and the "depleted" melt generates a declining trend of the ${ }^{3} \mathrm{He} /{ }^{4} \mathrm{He}$ ratio in the released gases. As helium isotopes can be directly related to a magma source and are very sensitive to kinetic fractionation, the decrease of the ${ }^{3} \mathrm{He} /{ }^{4} \mathrm{He}$ ratios can be interpreted as geochemical signals of magma ascent (Nuccio and Valenza, 1998; Caracausi et al., 2003; Capasso et al., 2005; Rizzo et al., 2006). The ${ }^{3} \mathrm{He} /{ }^{4} \mathrm{He}$ ratio returned back to normal values soon after the decrease. It could be generated either by the release of kinetically-enriched ${ }^{3} \mathrm{He}$ gas-bubbles during magma vesiculation (Nuccio and Valenza, 1998), or by the outgassing of new volatile-rich magma ascending from depth.

\subsection{Seismic data of the TVG area}

In addition to geological and geochemical evidence, volcanic seismicity also suggests that volcanic activity might not have yet become completely extinct. A seismic array consisting of five seismic stations installed in the TVG area since 2003 indicates that a large number of micro-earthquakes are clustering beneath the Chihsingshan volcano and DYK area (Yu and Tsai, 1980; Chen and Yeh, 1991; Lin et al., 2005a, b; Konstantinou et al., 2007). Most of those were volcano-tectonic earthquakes which were caused by brittle failure of rock and interpreted as related to fluid-rock interaction (Lin et al., 2005a, b; Konstantinou et al., 2007). In addition to those volcanotectonic earthquakes, volcano-seismic signals (tornillos, monochromatic events and high-frequency spasmodic bursts) were also detected among these micro-earthquakes. They have often been observed on active volcanoes worldwide, and some were detected before eruption (Chouet, 1996; McNutt, 1996; Kumagai, 2002). These signals are most probably associated with the direct/indirect interaction between hydrothermal or magmatic fluids and solid rock in the upper crust. Most of the spasmodic bursts events were detected in the DYK area. Taking all this evidence (active micro-earthquakes, special volcano-seismic signals and high ${ }^{3} \mathrm{He} /{ }^{4} \mathrm{He}$ ratio) into consideration, it is possible that the magmatic plumbing system beneath the TVG is still active.

\subsection{Models for the variations of fumarolic gas composition and temperature}

After a period of steady state for more than four years, fumarolic gas compositions of DYK began to change since August 2004, including a progressive increase of $\mathrm{HCl}$ concentrations and $\mathrm{SO}_{2} / \mathrm{H}_{2} \mathrm{~S}$ ratios. The outlet temperature of fumaroles was also higher than before. Moreover, the ${ }^{3} \mathrm{He} /{ }^{4} \mathrm{He}$ ratios decreased and soon returned to normal a few months after August 2004, and most of the spasmodic bursts events most probably associated with volcanic activity were largely concentrated in the DYK area (Lin et al., 2005a, b; Konstantinou et al., 2007). All these phenomena suggest that the magma chamber beneath DYK became more active during this period.

As described above, there could be two aquifers existing beneath the TVG area (Fig. 7A). The deeper one is closer to the magma source and can be considered as the primary hydrothermal system (PHS); nevertheless, the shallower one could be the secondary hydrothermal system (SHS) since the source origin of meteoric water. When volcanic gases migrate upward and pass through the deep aquifer, $\mathrm{HCl}$ and $\mathrm{SO}_{2}$ are dissolved easily because of their high solubility and, generate the acidic sulfate-chloride water. The low concentration of $\mathrm{HCl}$ and $\mathrm{SO}_{2}$ in gas compositions could be the result of mixing between meteoric water (i.e. the SHS) with the vapor phases generated by evaporation of PHS.

Two possible processes are considered here to explain these observations. One is that more magmatic fluids were released from the ascending magma in DYK (Fig. 7B). The other is that more magmatic fluids were released from the fractures opened recently (Fig. 7C) (Martini, 1996). Under the first process, the ascending magma could provide more magmatic fluids and heat to the system. As a result, both $\mathrm{HCl}$ concentration and $\mathrm{SO}_{2} / \mathrm{H}_{2} \mathrm{~S}$ ratio fluctuate with temperature (Giggenbach, 1996). $\mathrm{HCl}$ concentration and $\mathrm{SO}_{2} / \mathrm{H}_{2} \mathrm{~S}$ ratio increased as temperature increased in DYK area. The decrease 


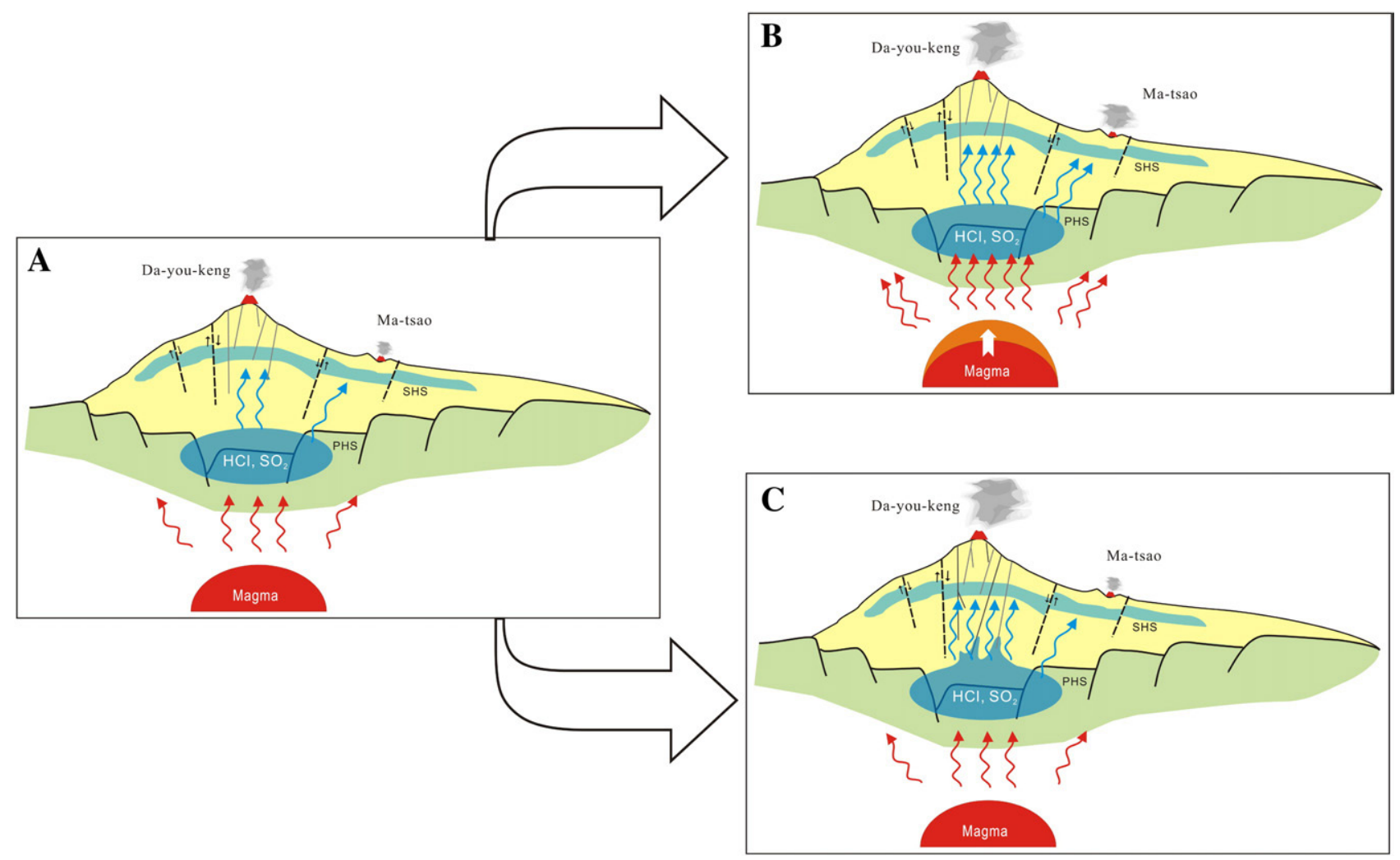

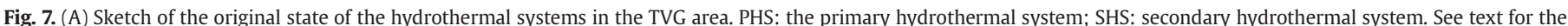

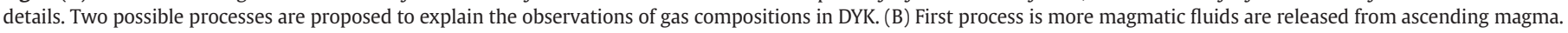

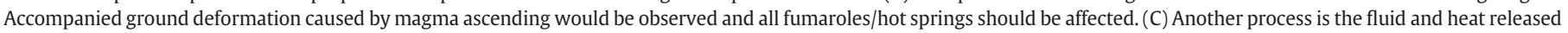
through the recently opened fractures. These fractures may provide the pathway for both gases from a crustal component and heat.

of ${ }^{3} \mathrm{He} /{ }^{4} \mathrm{He}$ ratio could be caused by kinetic fractionation. However, if more magmatic fluids injected into the PHS, not only DYK but all other areas should be influenced.

The other process involves release of deeper fluid and heat through newly developed fractures (Fig. 7C). This is consistent with the tectonics of northern Taiwan which is under a sustained extension due to the opening of the Okinawa Trough (Teng, 1996; Wang et al., 1999). Such a process could explain the variations in $\mathrm{HCl}$ concentration and $\mathrm{SO}_{2} / \mathrm{H}_{2} \mathrm{~S}$ ratio, and the trend in ${ }^{3} \mathrm{He} /{ }^{4} \mathrm{He}$ ratio as well. According to seismic data, most of the spasmodic bursts events, often associated with the interaction between hydrothermal or magmatic fluids and solid rock in the upper crust, were located in the DYK area. Therefore, more magmatic fluid ascended along these fractures only in the DYK area and caused the increase of $\mathrm{HCl}$ concentration and $\mathrm{SO}_{2} /$ $\mathrm{H}_{2} \mathrm{~S}$ ratio. A short-term negative anomaly of ${ }^{3} \mathrm{He} /{ }^{4} \mathrm{He}$ ratios of the gas samples indicates that the crustal component affected the DYK degassing system instantaneously. The fracturing process can explain why we did not observe ground deformation here, and seems to be more suitable to account for all observations in DYK. However, one problem arises: all our observations should happen synchronously; however, ${ }^{3} \mathrm{He} /{ }^{4} \mathrm{He}$ ratios varied in a few months later than other parameters ( $\mathrm{HCl}$ concentration, $\mathrm{SO}_{2} / \mathrm{H}_{2} \mathrm{~S}$ ratio, and temperature). One possible explanation is that less crustal components were added at the beginning; therefore, variation in ${ }^{3} \mathrm{He} /{ }^{4} \mathrm{He}$ ratio was not observable. On the other hand, variations in $\mathrm{HCl}$ concentration, $\mathrm{SO}_{2} /$ $\mathrm{H}_{2} \mathrm{~S}$ ratio and temperature were more sensitive so that they were observed earlier.

\section{Concluding remark}

Fumarolic gas compositions of DYK varied since August 2004. Progressive increases were observed not only in $\mathrm{HCl}$ concentration but also in $\mathrm{SO}_{2} / \mathrm{H}_{2} \mathrm{~S}$ ratio. The outlet temperature of fumaroles was also higher than before. Moreover, ${ }^{3} \mathrm{He} /{ }^{4} \mathrm{He}$ ratio changed in a few months after August 2004. ${ }^{3} \mathrm{He} /{ }^{4} \mathrm{He}$ ratios showed a decreasing trend which returned to normal after approximately 6 months. These anomalies were only observed in the DYK area. Combining the helium isotopic ratios and volcano-seismic data, we suggest that a magma chamber might still exist beneath the TVG area, particularly in the area of DYK.

A short-term decreasing trend of ${ }^{3} \mathrm{He} /{ }^{4} \mathrm{He}$ ratios of the gas samples indicates that the proportion of crustal component was increasing for only a pulse of its gas sources. Alternatively kinetic fractionation of helium isotopes due to degassing of ascending magma may explain the observed trend. Because there is no ground deformation and no abnormality in gas compositions in any other area, we consider these variations might be caused by recent opening of fractures in a local area. More magmatic or primary hydrothermal fluid ascended along these fractures and likely caused the increase of $\mathrm{HCl}$ concentration and $\mathrm{SO}_{2} / \mathrm{H}_{2} \mathrm{~S}$ ratio.

\section{Acknowledgements}

We thank Mr. K. W. Wu and B. W. Lin for their assistance in collecting samples and helium isotopic analysis. Drs. A. Caprai, China Chen, T. Fischer, T. Ohba, Y. Sano, Y. Taran, O. Vaselli and G. Zellmer gave constructive comments/suggestions in different stages of this work. Drs. Y. Taran and S. Inguaggiato reviewed the paper and gave critical comments to improve the manuscript. Dr. T. Fischer carefully edited the revised manuscript and gave useful comments. National Science Council (TFY/NSC96-2628-M002-026), Yangmingshan National Park and Central Geological Survey (TFY/5226902000-05-93-01) of Taiwan financially support this study. 


\section{References}

Aiuppa, A., Federico, C., 2004. Anomalous magmatic degassing prior to the 5th April 2003 paroxysm on Stromboli. Geophysical Research Letters 31, L14607. doi:10.1029/ 2004GL020458.

Aiuppa, A., Moretti, R., Federico, C., Giudice, G., Gurrieri, S., Liuzzo, M., Papale, P., Shinohara, H., Valenza, M., 2007. Forecasting Etna eruptions by real-time observation of volcanic gas composition. Geology 35, 1115-1118.

Aramaki, S., 1991. Hazardous volcanic eruptions in Japan. Episode 14, 264-268.

Capasso, G., Favara, R., Inguaggiato, S., 1997. Chemical features and isotopic composition of gaseous manifestations on Vulcano Island (Aeolian Islands, Italy): an interpretative model of fluid circulation. Geochimica et Cosmochimica Acta 61, 3425-3440.

Capasso, G., Carapezza, M.L., Federico, C., Inguaggiato, S., Rizzo, A., 2005. Geochemical monitoring of the 2002-2003 eruption at Stromboli volcano (Italy): precursory changes in the carbon and helium isotopic composition of fumarole gases and thermal waters. Bulletin of Volcanology 68, 118-134. doi:10.1007/s00445-0050427-5.

Caracausi, A., Favara, R., Giammanco, S., Italiano, F., Paonita, A., Pecoraino, G., Rizzo, A., Nuccio, P.M., 2003. Mount Etna: geochemical signals of magma ascent and unusually extensive plumbing system. Geophysical Research Letters 30 (2), 1057. doi:10.1029/2002GL015463.

Carapezza, M.L., Inguaggiato, S., Brusca, L., Longo, M., 2004. Geochemical precursors of the activity of an open-conduit volcano: the Stromboli 2002-2003 eruptive events. Geophysical Research Letters 31, L07620. doi:10.1029/2004GL019614.

Chen, C.-H., Lin, S.B., 2002. Eruptions younger than 20 ka of the Tatun Volcano Group as viewed from the sediments of the Sungshan Formation in Taipei Basin. Western Pacific Earth Sciences 2, 191-204.

Chen, C.H., 1970. Geology and geothermal power potential of the Tatun volcanic region. UN Symposium on the Development and Utilization of Geothermal Resources 2, 1134-1143.

Chen, C.H., Wu, Y.J., 1971. Volcanic geology of the Tatun geothermal area, northern Taiwan. Proceedings of the Geological Society of China 14, 5-20.

Chen, C.T.A., Zeng, Z., Kuo, F.W., Yang, T.F., Wang, B.J., Tu, Y.Y., 2005. Tide-influenced acidic hydrothermal system offshore NE Taiwan. Chemical Geology 224, 69-81.

Chen, K.J., Yeh, Y.H., 1991. Gravity and microearthquake studies in the ChinshanTamshui area, northern Taiwan. Terrestrial, Atmospheric and Oceanic Sciences 2, 35-50.

Chen, Y.L., Lo, H.J., Song, S.R., Fang, J.N., Huang, S.C., Chen, H.F., 2001. Chemical compositions of hot spring waters at Direku and Chingshan in the Tatun volcanic area, northern Taiwan. Western Pacific Earth Sciences 1, 187-198.

Chiodini, G., Cioni, R., Marini, L., 1993. Reactions governing the chemistry of crater fumaroles from Vulcano Island, Italy, and implications for volcanic surveillance. Applied Geochemistry 8, 357-371.

Chouet, B.J., 1996. Long-period volcano seismicity: its source and use in eruption forecasting. Nature 380, 309-316.

Duffell, H.J., McGonigle, A.J.S., Burton, M.R., Oppenheimer, C., Pyle, D.M., Galle, B., 2003. Changes in gas composition prior to a minor explosive eruption at Masaya volcano, Nicaragua. Journal of Volcanology and Geothermal Research 126, 327-339.

Fischer, T.P., 2008. Fluxes of volatiles $\left(\mathrm{H}_{2} \mathrm{O}, \mathrm{CO}_{2}, \mathrm{~N}_{2}, \mathrm{Cl}, \mathrm{F}\right)$ from arc volcanoes. Geochemical Journal 42 (1), 21-38.

Fischer, T.P., Arehart, G.B., Sturchio, N.C., Williams, S.N., 1996. The relationship between fumarole gas composition and eruptive activity at Galeras volcano, Colombia. Geology 24, 531-534.

Giammanco, S., Inguaggiato, S., Valenza, M., 1998. Soil and fumarole gases of Mount Etna: geochemistry and relations with volcanic activity. Journal of Volcanology and Geothermal Research 81, 297-310.

Giggenbach, W.F., 1975. A simple method for the collection and analysis of volcanic gas samples. Bulletin of Volcanology 36, 132-145.

Giggenbach, W.F., 1987. Redox processes governing the chemistry of fumarolic gas discharges from White Island, New Zealand. Applied Geochemistry 2, 143-161.

Giggenbach, W.F., 1992. The composition of gases in geothermal and volcanic systems as a function of tectonic setting. Proc. Int'l Symp. Water-Rock Interaction 8, 873-878.

Giggenbach, W.F., 1996. Chemical composition of volcanic gases. In: Scarpa, R., Tillinh, R.I. (Eds.), Monitoring and Mitigation of Volcanic Hazards. Springer, Berlin, pp. 221-256.

Goff, F., McMurtry, G.M., 2000. Tritium and stable isotopes of magmatic waters. Journal of Volcanology and Geothermal Research 97, 347-396.

Haughton, D.R., Roeder, P.L., Skinner, B.J., 1974. Solubility of sulfur in mafic magmas. Economic Geology 69, 451-463.

Hirabayashi, J., Ossaka, J., Ozawa, T., 1986. Geochemical study on volcanic gases at Sakurajima volcano, Japan. Journal of Geophysical Research 91 (B12), 2167-2176.

Hirabayashi, J., Shinohara, H., 1989. Sampling and analytical methods of volcanic gases. Textbook for the Group Training Course in Volcanology and Volcanic Engineering, vol. II. Japan International Cooperation Agency (JICA).

Juang, W.S., Chen, J.C., 1989. Geochronology and geochemistry of volcanic rocks in northern Taiwan. Bulletin of Central Geological Survey 5, 31-66.

Konstantinou, K.I., Lin, C.H., Liang, W.T., 2007. Seismicity characteristics of a potentially active Quaternary volcano: the Tatun Volcano Group, northern Taiwan. Journal of Volcanology and Geothermal Research 160, 300-318.

Kumagai, H., 2002. Temporal evolution of a hydrothermal system in Kusatsu-Shirane Volcano, Japan, inferred from the complex frequency of long-period events. Journal of Geophysical Research 107 (B10), 2236. doi:10.1029/2001JB000653.

Lan, T.F., Yang, T.F., Lee, H.F., Chen, Y.G., Chen, C.-H., Song, S.R., Tsao, S., 2007. Compositions and flux of soil gases in hydrothermal area, Northern Taiwan. Journal of Volcanology and Geothermal Research 65, 32-45.
Lee, H.F., 2004. Compositions of fumarolic gases and the H-O isotopic ratios of the condensed water in Tatun Volcanic area, North Taiwan. MS Thesis, Institute of Geosciences, National Taiwan University, 83 pp. (in Chinese).

Lee, H.F., Yang, T.F., Lan, T.F., Song, S.R., Tsao, S., 2005. Fumarolic gas composition of the Tatun Volcano Group, northern Taiwan. Terrestrial, Atmospheric and Oceanic Sciences 16, 843-864.

Lin, C.H., Konstantinou, K.I., Liang, W.T., Pu, H.C., Lin, Y.M., You, S.H., Huang, Y.P., 2005a. Preliminary analysis of volcanoseismic signals recorded at the Tatun Volcano Group, northern Taiwan. Geophysical Research Letters 32, L10313. doi:10.1029/2005GL022861.

Lin, C.H., Konstantinou, K.I., Pu, H.C., Hsu, C.C., Lin, Y.M., You, S.H., Huang, Y.P., 2005b. Preliminary results of seismic monitoring at Tatun volcanic area of northern Taiwan. Terrestrial, Atmospheric and Oceanic Sciences 16, 563-577.

Liu, K.K., Chen, C.C., Shieh, Y.N., Chiang, S.C., 1984. Carbon, oxygen and hydrogen isotope studies of Tatun geothermal area in Taipei. Report of Institute of Earth Sciences. Academia Sinica: ASIES-CR 840139 pp. (in Chinese).

Martini, M., 1996. Chemical characters of the gaseous phase in different stages of volcanism: precursors and volcanic activity. In: Scarpa, R., Tillinh, R.I. (Eds.), Monitoring and Mitigation of Volcanic Hazards. Springer, Berlin, pp. 199-219.

Marty, B., Jambon, A., Sano, Y., 1989. Helium isotopes and $\mathrm{CO}_{2}$ in volcanic gases in Japan. Chemical Geology 76, 25-40.

McNutt, S.R., 1996. Seismic monitoring and eruption forecasting of volcanoes: a review of the state-of-the-art and case histories. In: Scarpa, R., Tillinh, R.I. (Eds.), Monitoring and Mitigation of Volcanic Hazards. Springer, Berlin, pp. 100-146.

Menyailov, I.A., Nikitina, L.P., Shapar, V.N., Pilipenko, V.P., 1986. Temperature increase and chemical-change of fumarolic gases at Momotombo Volcano, Nicaragua, in 1982-1985 - are these indicators of a possible eruption? Journal of Geophysical Research 91 (B12), 2199-2214.

MRSO, 1969. The geothermal exploration of the Tatun Volcano Group (I). MRSO Report, 90. 63 pp. (in Chinese).

MRSO, 1970. The geothermal exploration of the Tatun Volcano Group (II). MRSO Report, 102. 86 pp. (in Chinese).

MRSO, 1971. The geothermal exploration of the Tatun Volcano Group (III). MRSO Report, 111. 48 pp. (in Chinese).

MRSO, 1973. The geothermal exploration of the Tatun Volcano Group (IV). MRSO Report 126. 78 pp., (in Chinese).

Noguchi, K., Kamiya, H., 1963. Prediction of volcanic eruption by measuring the chemical composition and amounts of gases. Bulletin of Volcanology 26, 367-378.

Notsu, K., Nakai, S., Igarashi, G., Ishibashi, J., Mori, T., Suzuki, M., Wakita, H., 2001. Spatial distribution and temporal variation of ${ }^{3} \mathrm{He} /{ }^{4} \mathrm{He}$ in hot spring gas released from Unzen volcanic area, Japan. Journal of Volcanology and Geothermal Research 111, 89-98.

Nuccio, P.M., Valenza, V., 1998. Magma degassing and geochemical detection of its ascent. In: Arehart, G.B., Hulston, J.R. (Eds.), Water-Rock Interaction. Balkema, pp. 475-478.

Ohnishi, T., Kamada, M., 1981. Correlation between minor constituents of volcanic gas at Mochiki and volcanic activity of Sakurajima Volcano. Paper Presented at 1981 IAVCEI Symposium.

Oskarsson, N., 1984. Monitoring of fumarole discharge during the 1975-1982 rifting in Krafla volcanic center, North Iceland. Journal of Volcanology and Geothermal Research 22, 97-121.

Pecoraino, G., Giammanco, S., 2005. Geochemical characterization and temporal changes in parietal gas emissions at Mt. Etna (Italy) during the period July 2000July 2003. Terrestrial, Atmospheric and Oceanic Sciences 16, 805-841.

Poreda, R., Craig, H., 1989. Helium isotope ratios in circum-Pacific volcanic arcs. Nature $338,473-478$.

Rizzo, A., Caracausi, A., Favara, R., Martelli, M., Nuccio, P.M., Paonita, A., Rosciglione, A. Paternoster, M., 2006. New insights into magma dynamics during last two eruptions of Mount Etna as inferred by geochemical monitoring from 2002 to 2005. Geochemistry Geophysics Geosystems 7, Q06008. doi:10.1029/2005GC001175.

Sano, Y., Wakita, H., 1985. Geographical distribution of ${ }^{3} \mathrm{He} /{ }^{4} \mathrm{He}$ ratios in Japan: implications for arc tectonics and incipient magmatism. Journal of Geophysical Research 90, 8729-8741.

Sano, Y., Nakamura, Y., Wakita, H., 1984. Helium-3 emission related to volcanic activity Science 224, 150-151.

Song, S.R., Tsao, S.J., Lo, H.J., 2000a. Characteristics of the Tatun volcanic eruptions, north Taiwan: implications for a cauldron formation and volcanic evolution. Journal of the Geological Society of China 43, 361-378.

Song, R.S., Yang, T.F., Yeh, Y.H., Tsao, S., Lo, H.J., 2000b. The Tatun volcano group is active or extinct? Journal of the Geological Society of China 43, 521-534.

Symonds, R.B., Rose, W.I., Bluth, G.S.J., Gerlach, T.M., 1994. Volcanic gas studies: methods, results, and applications. In: Carrol, M.R., Holloway, J.R. (Eds.), Volatiles in Magma. Review of Mineralogical Society of America, Washington DC, pp. 1-64.

Teng, L.S., 1996. Extensional collapse of the northern Taiwan mountain belt. Geology 24 949-952.

Teng, L.S., Chen, C.-H., Wang, W.S., Liu, T.K., Juang, W.S., Chen, J.C., 1992. Plate kinematic model for late Cenozoic arc magmatism in northern Taiwan. Journal of the Geological Society of China 35,1-18.

Tsao, S.J., 1994. Potassium-argon age determination of volcanic rocks from the Tatun Volcano Group. Bulletin of Central Geological Survey 9, 137-154.

Walker, G.P.L., 1974. Volcanic hazards and the prediction of volcanic eruptions. In: Funnell B.M. (ed.), Prediction of geological hazards. Geological Society of London, Miscellaneous Paper, 3, 23-41.

Wallace, P., Carmichael, I.S.E., 1992. Sulfur in basaltic magmas. Geochimica et Cosmochimica Acta 56, 1863-1874.

Wang, K.L., Chung, S.L., Chen, C.H., Shinjo, R., Yang, T.F., Chen, C.-H., 1999. Post-collisional magmatism around northern Taiwan and its relation with opening of the Okinawa Trough. Tectonophysics 308, 363-376. 
Wang, W.H., Chen, C.-H., 1990. The volcanology and fission track age dating of pyroclastic deposits in Tatun Volcano Group. Acta Geologica Taiwanica 28, 1-30.

Witt, M.L.I., Fischer, T.P., Pyle, D.M., Yang, T.F., Zellmer, G.F., 2008. Fumarole compositions and mercury emissions from the Tatun Volcanic Field, Taiwan: results from multi component gas analyser, portable mercury spectrometer and direct sampling techniques. Journal of Volcanology and Geothermal Research 178, 638-645 (this issue).

Yang, T.F., 2000. ${ }^{3} \mathrm{He} /{ }^{4} \mathrm{He}$ ratios of fumaroles and bubbling gases of hot springs in Tatun Volcano Group, North Taiwan. Journal of National Park 10 (1) 73-94 (in Chinese).

Yang, T.F., Sano, Y., Song, S.R., 1999. ${ }^{3} \mathrm{He} /{ }^{4} \mathrm{He}$ ratios of fumaroles and bubbling gases of hot springs in Tatun Volcano Group, North Taiwan. Nuovo Cimento Della Societa Italiana Di Fisica C22 (3-4), 281-286.

Yang, T.F., Chen, C.-H., Tien, R.L., Song, S.R., Liu, T.K., 2003a. Remnant magmatic activity in the Coastal Range of East Taiwan after arc-continent collision: fission-track date and ${ }^{3} \mathrm{He} /{ }^{4} \mathrm{He}$ ratio evidence. Radiation Measurements 36, 343-349.
Yang, T.F., Ho, H.H., Hsieh, P.S., Liu, N.J., Chen, Y.G., Chen, C.-H., 2003b. Sources of fumarolic gases from Tatun Volcano Group, North Taiwan. Journal of National Park 13, 127-156 (in Chinese).

Yang, T.F., Lan, T.F., Lee, H.F., Fu, C.C., Chuang, P.C., Lo, C.H., Chen, C.-H., Chen, C.T.A., Lee, C.S., 2005. Gas compositions and helium isotopic ratios of fluid samples around Kueishantao, NE offshore Taiwan and its tectonic implications. Geochemical Journal 39, 469-480.

Yang T.F Chuang P.C. Lin, S. Chen, J.C. Wang, Y., Chung, S.H, 2006. Methane venting in gas hydrate potential area offshore of SW Taiwan: evidence of gas analysis of water column samples. Terrestrial, Atmospheric and Oceanic Sciences 17, 933-950.

Yen, T.P., Tzou, Y.H., Lin, W.H., 1984. Subsurface geology of the region of the Tatun Volcano Group. Petroleum Geology of Taiwan 20,143-154.

Yu, S.B., Tsai, Y.B., 1980. Micro-earthquakes and seismic tremors in the Tatun volcanic area. Open-File Rept., Inst. Earth Sci., Academia Sinica, 68 pp. 